\title{
A Living Heritage Approach Toward Sustainability of Islamic City in The Northern Coastal of Java, Indonesia
}

\author{
Atik Suprapti \\ Department of Architecture, Faculty of Engineering, Universitas Diponegoro, Semarang, Indonesia \\ Corresponding e-mail: atiksuprapti@arsitektur.undip.ac.id
}

Article info:

Received: 30-11-2021, Revised: 1-12-2021, Accepted: 2-12-2021

\begin{abstract}
Cultural diversity is one of global issue underlined by United Nation. Indonesia known as a very rich country has more than 300 ethnic cultures. One of them is the Islamic architecture and cities that spread in the Northern Coastal of Java. In the span of 6 centuries, we can still witness the existence of these works as living heritage that saves tangible and intangible cultures. The role of the community is very significant in taking care, planning and developing for the next generation. However, the changes that have occurred are caused by urbanization, and the shift in the political and economic map poses a threat to the sustainability of this legacy. The purpose of writing the article is to provide views on the importance of an approach to the process of preserving living heritage by involving community participation in order to maintain the sustainability of cultural heritage. The locus in the Northern Coastal of Java is based on consideration that the cities inherit the distinctive Islamic culture of the Coastal of Java and its dynamics. The digital-legacy approach combines the use of information technology in this case is Web GIS for archiving artifact data. Meanwhile, the living heritage approach encourages community participation to play an active role with stakeholders in line to the preservation of artifacts. One of the potential heritage Islamic city is the Kudus Kulon historic city. It is an interesting and unique case with the Gusjigang community who have cared for omah joglo pencu for almost three centuries. Architectural sustainability - Muslim cities include historical and cultural sustainability, function, and maintenance.
\end{abstract}

Keywords: living heritage, sustainable, Islamic city.

\section{Introduction}

One of the sustainable development targets (Sustainable Development Goals) formulated by Sustainable City and Community, which covers what has been UNESCO (United Nations Educational, Scientific and Cultural Organization) launched by encouraging the protection of cultural and natural heritage. Consider to the sustainability of cultural values in the era of urbanization has become one of the world's issues, one of which is related to the impact of urbanization on cultural conservation and local wisdom (Lang, Chen, \& Li, 2016). Some cases in Asia, particularly for developing countries such as Indonesia, include the problem of managing cultural heritage settlements (Suprapti, Kim, Pandelaki, \& Firmandhani, 2018). The fact that looks real is the shift in architectural values from traditional to modern, in this case from Javanese to modern civilization. A Muslim city is defined as a city that grew under the influence of Islamic civilization and developed as a place of residence for the Muslim community. Islam religion is embraced by 1.8 billion people worldwide, Muslim communities spread in Asia Pacific countries, Middle East, North Africa, Europe, etc. Indonesia is the country with the largest Muslim population in the world, with 220 million people below which are Pakistan and India. In various parts of the world, Muslim cities grow with each locality with a distinctive character influenced by Islamic law (Abu-Lughod, 1987; Hakim, 1986). Saoud (2002) underlines that the plan and shape of an Islamic city is influenced by several factors such as the structure of the city. socio-cultural, political, and economic. According to Saoud 
(2002), the principles of Muslim city design must accommodate several aspects including natural law, religious and cultural beliefs, sharia law, and social principles. Al-Qahtany (2009) further emphasized that the Islamic city is a social phenomenon in architecture and planning which is shaped by intellectual, social and environmental aspects which are exemplified from the traditional settlement of Samarra, Iraq and the Ottoman city, which is interactionalism. Meanwhile Raymond (1994) argues that the Islamic city in the case of the Arab City is a market city, he views that the Islamic city was founded from the combination of the market (suq) and the great mosque. From the research of Abu-Lughod (1987); Judge (1986); Raymond (1994); Saoud (2002) shows that there is continuity in Islamic cities which structurally includes the Great Mosque, suq (road network), palaces, and housing, and these cities and the continuity can still be seen today. Meanwhile, Javanese Islamic cities emerged since the 15th century and became a political strategy in the era of the Demak Sultanate. The city was designed by the Sultan in a 'mancapat mancalima', a configuration which includes the palace, alun-alun (open space), grand mosque, market, and settlements of ethnic groups. One of them was developed by Kampung Kauman, which is the settlement of santri (the students of traditional Islamic boarding school) around the Jami mosque. Kampung Kauman has a transcendental character constructed from time, social cohesion, economic activity, and strong religious teachings (Suprapti, 1997), and has strong social control to protect its existence (Suprapti, 2017).

Continuity occurs on a change that adapts to the needs of the community, made possible by adding functions, so that it is possible to form sustainable preservation that focuses on diversity, continuity, community, and conservation. Sustainability allows the connection between the past and the present to continue. One of the important parts in a city is social life, in which there are ethnic dimensions of population, history, economic factors, politics, morphology, visuals, etc. The reciprocal relationship between the physical environment and the social life of the city is conveyed by Rapoport (2002). Socio-cultural conditions such as norms, views of life, values, ideas, lifestyle are factors that play an important role in the place of residence (the built environment). This is implemented in an agreement on standards, space organization, the use of space-forming elements. The dynamics of the built environment is influenced by the central role of humans in it, which is related to kinship, family structure, networking. Meanwhile, Hillier \& Hanson (1988) conveyed that urban structure and spatial networks have a very important influence on social life. The city is composed of several different layers, namely the structural layer formed by the road network and public spaces, the building layer such as buildings, greenery, and the socio-cultural layer including the population and with various differences such as culture, history, social structure (Legeby, 2013). The involvement of human culture in space is known as place (Hayden, 1994; Lynch, 1960; Norberg-Schulz, 1983; Rapoport, 2002; Trancik, 1986). Place involves psychological aspects of space such as feeling comfortable, at home, happy, emotional, sad, surprised, and all human behaviour (Mikelides, 1980). community, as well as related to the relationship between the built environment and quality of life. The Northern Coastal of Java is known in history as the gateway for the entry of Islamic teachings by Walisanga. Walisanga is known as the nine holy figures who spread Islam in Java who lived in the 14th century. Walisanga heritage sites that spread along the Northern Coastal of Java, can be grouped into three zones. The first is the East zone, covering Surabaya, Gresik; the two Central Zones include Demak, Kudus, Rembang, Lasem; West Zone is Cirebon. The passage of time about 6 centuries allows cultural changes, both tangible and intangible. One important note of this change is the existence of 
communities that have coexisted throughout history with functions that tend to remain unchanged from the original.

\section{Methods}

In writing this article, descriptive analytical methods are used combined with architectural spatial analysis techniques. Sources of data in the form of primary data obtained from interviews, group discussion forums with informants and direct observations in the field; Meanwhile, secondary data are in the form of maps, pictures, web, documents from other people's research as well as from the authors themselves, related journals. Conducted (1) descriptive analysis by describing and explaining as well as seeing the relationship between issues, as well as analysing the relationship between issues and references, (2) spatial analysis to determine aspects related to spatial planning and spatiality, (3) architectural typology analysis to determine architectural characteristics of artifacts, and (4) digital mapping for documenting building and environmental data. For the digital mapping step were run analysis and systemizes all data from various sources such of field observation, interviews, literatures. Then the step is to arrange the data by grouping, which were presented to the form of percentages, patterns, maps and narratives. Quickbird satellite imagery for time series were used to identify building density variable. Interpretation technique of satellite image and GIS were used in order to test the validity data accuracy.

\section{Discussion}

The Walisanga heritage site which spreads from Surabaya to Cirebon at this time has become a very meaningful and valuable tourist asset. Economically, this can bring material benefits because it is associated with tourism. From historical legends, local wisdom is inherited in the form of cultural values and artifacts that are still upheld by the community. Visits of pilgrims in a tour package to the Walisanga site by local and foreign tourists from time to time are increasing. This phenomenon has opened up opportunities for the growth of the people's economy, especially in religious tourism. The history of Islamic cities in Java starts from the northern coast of Java as a gateway for the entry of Islamic teachings. Acculturation between Hindu, Buddhist and Islamic cultures forms the specific character of a Javanese Muslim city. The Javanese-Islamic cosmic city forms a distinctive spatial configuration and spreads across the coastal and inland areas of Java. In the implementation of this cosmic city configuration, it is known as "Catur Sagatra", which includes the palace, square, mosque, market, and settlements located in the vicinity. Catur Sagatra is a concept of cosmological balance in an Islamic city in Java. The location of the oldest Islamic city in Java can be seen in the old city of Demak. The capital of the first Islamic Sultanate of Demak Bintoro (1487-1546) has a city structure that looks simple. The elements of a Javanese Islamic city that adopt the concept of the city of Majapahit Kingdom which includes the palace, square, grand mosque, market, and settlements of ethnic groups such as Kauman \& Chinatown. The structure Demak city can be seen in Figure -1 which was built from the agreement of the Walis (member of Walisanga) who had a mission to spread Islamic teachings to western Java and the archipelago (Al-Qurtubi \& Al-Ansari, 1964). The city of Demak developed from a small pesantren (a traditional Islamic boarding school) and a mosque founded by Raden Patah in the Glagah Wangi area which later developed into a bustling port, from which the Islamic state of Demak Bintoro was founded. The location selection shows the strategic location of the city, located to the south of the Mount Muria which is believed to be a sacred place and to the west of the Tuntang River which is the source of life and has religious meaning, as well as the meaning of defence and security. The Muslim city in the Northern Coastal of Java is a living legacy of six centuries of 
history. The character of the city is shaped by a culture that is rooted in everyday life, combining tangible and intangible cultures. These cities are experiencing changes mainly due to urbanization pressures that hit most of the world's cities. Political and economic changes also place the Islamic city of coastal of Java in an increasingly unfavourable situation, resulting in a lot of degradation, especially the assets of the city's cultural history. Researches in the field of architecture and urban areas are considered quite a lot related to the Islamic city of the Northern Coastal of Java, however the question arises, how is the solution to the problem of a heritage city with cultural artifacts that are values degraded and increasingly pressured by this urbanization flow..? how academically to provide benefits from the results of research that has been done previously for the benefit of the wider community, in this case for the conservation of the living heritage area of the Muslim city at the Norther Coastal of Java, with that way can promote knowledges and bring benefits to society today and for future generations.
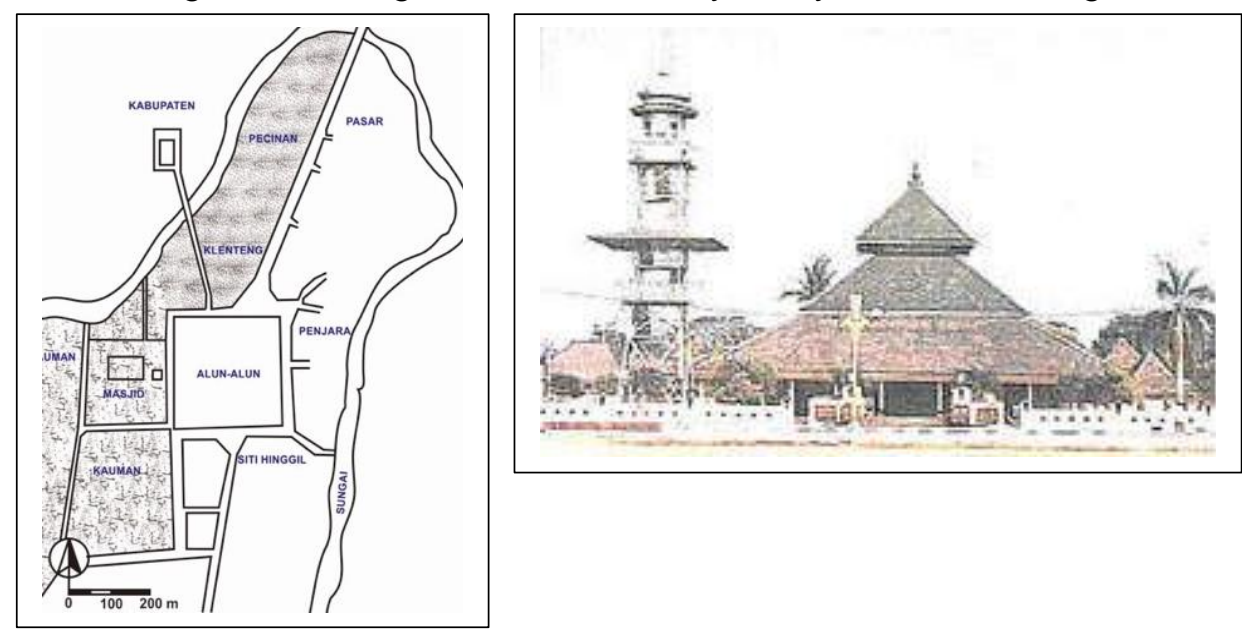

Figure 1

Left: The structural elements of the Demak City include: Alun-Alun, Siti Hinggil, the Great Mosque, and Residential Villages such as Chinatown, and Kauman.

Right: The Demak Mosque was built by Walisanga as an architectural model for the Javanese Mosque, with a three-tiered tajug roof. This model is widely used for jami' mosques in the coastal and inland areas. (Source: Wiryotomo, 1995)

\subsection{Sustainability of Ancient Cities in the Northern Coastal of Java}

The concept of Sustainable Development is based on the Rio Declaration at the Earth Summit in 1992, the United Nations Millennium Declaration in 2000, and the Johannesburg Declaration at the 2002 Earth Summit. The Earth Summit Declaration, 2005, that defines as development that meets the needs of the present by taking into account the fulfilment of the needs of generations to come. future (Brundtland, 1987). Sustainable Development is an interaction between three systems, which are the economic system, the natural resource system, and the social system (Stern, While \& Whitney, 1992). The concept of sustainable development found a meeting point with the Universal Declaration of Cultural Diversity by UNESCO in 2001. In 2017 the world institution through the Assistant Director General of UNESCO for Culture (ADG Culture) Francesco Bandarin at a meeting in Paris acknowledged that, Indonesia is a super power country in Indonesia. cultural field. This abundant tangible (object) and intangible (intangible) cultural wealth needs to be appreciated and managed properly by the entire Indonesian nation. This will be beneficial for science, strengthening national identity and social harmonization, and can bring benefits in the economic field. One of Indonesia's prominent cultural heritages is the Islamic cities in the North Coast of Java which have local wisdom and are evidences of the spread of Islam in Java by Walisanga, the glory of the Islamic Kingdom of Demak up to Mataram and up to the present time. The success of these cities and their sustainability for the 6 'th centuries in maintaining and preserving socio-cultural life beyond 
civilization changes is an interesting to be learned and developed, in order to bring benefits to the current and future generation.

Culture is a complex whole, which includes knowledge, belief, art, morals, law, customs, and other capabilities (Tylor, 2010). Meanwhile, in the classical definition presented by Vitruvius (1787) architecture includes three aspects, namely beauty (venustas), strength (firmitas) and utility (utility). From the description it is shown that architecture is a strong element of culture. Architecture (artifact) is a symbol of the embodiment of cultural values that live and are rooted in a particular society. Because basically architecture is an expression of cultural symbols. A distinctive culture will contribute to a distinctive architectural work as well. Underlining this, Rapoport (1969) said that architecture is a residential building that is influenced by sociocultural factors (community customs), in addition to modifying factors. Distinguished guests, the entry of Islamic teachings in Java in the 15th century as a new belief in the midst of the influence of the old culture was based on a smooth process of acculturation (Al-Qurtubi \& AlAnsari, 1964), in this case among the lower-class society. Walisanga who are Sufis and spread Islamic teachings through trade intermediaries, through acculturation, smoothly and can be accepted by the people (Lombard, 1975; Tjandrasasmita, 2000). Pesantren is referred to Islamic boarding school as the oldest educational institution in Indonesia in the 16th centuries introduced by Sunan Ampel. In its socio-historical journey has contributed greatly to the formation of the nation and state (Fadilah, 2011). Besides being an important pillar in the history of Indonesian education (Muhakamurrohman et al., 2014). Islamic boarding schools are led by ulama/kyai (religious leaders) as traditional religious educational institutions that not only teach of religious knowledge, but also the values of simplicity, independence, cooperation, solidarity and sincerity (Muhakamurrohman et al., 2014). The role of pesantren is quite large in the socio-cultural development of the Indonesian nation, including resistance to colonialism (Hielmy, 2000; Rahman \& Wahab, 2004; Soedjoko, 1982). So that this pesantren has succeeded in mobilizing awareness of resistance to Dutch colonialism, strengthening the education system, organizing organizations that are oriented to socio-economic aspects, awareness to return to Islamic teachings originating from the Qur'an and Hadith. The history of the founding of the Demak Sultanate (1487-1743) has a strong relation to the Sunan Ampel Islamic boarding school, because Raden Patah (founder and first Sultan of Demak) was a student or santri. From this pesantren, the phenomenal Great Mosque of Demak was built and functioned as a center for the spread of Islam, socio-cultural development, and a place to discuss state politics. After the Demak Sultanate was established, the mosque developed into the Great Mosque and around the mosque developed into a residence for religious leaders who later became known as the Kauman village (Darban, 1984), here the settlements of the students developed. A similar spatial pattern is found in Kudus Kulon which was developed by Jak'ar Sidiq (Sunan Kudus). He established the Al-Aqsa mosque and the Kudus Tower, and soon around it was the Kauman settlement (Suprapti et al., 2018). The Great Mosque is the main element constructing the Islamic city of Demak and Kudus in addition to the square (alunalun), palace, and market. Religious education institutions serve education for children from pre-school and kindergarten. This is very importance to embody the children's character (Suprapti et al, 2012; Ainiyah, 2013). Character education as moral education, is needed from the age of children to adults (Sari et al., 2016), so that a Muslim has noble character which is called akhlakul kharimah. The establishment of the Kauman village in the city center was continued in the Mataram era in the capital cities of the Kingdom. And in the colonial era, the Dutch adopted the concept of this Javanese Islamic city spatial pattern to be applied to Residency and Regency cities formed by the Dutch aimed at controlling power (Suprapti et al., 2018), have strengthened the control of settlement space rooted in religious ideology.

The growing crowds from the ports of Tuban, Gresik, Surabaya, Sedayu, Jepara, Banten, with foreign traders from Arabia, Persia, India, China, (Darmawijaya 2010, Purwadi 2001), indicated the Demak region became the market center in the Asian region. Southeast with the mainstay commodities of spices and rice supplied from Java and other Archipelago Islands. Due to its 
strategic location, Demak has grown as a maritime-trade country. The economic surplus is obtained from trade in agricultural products and taxation of goods in and out of ports. The porter who was usually held by the aristocrats or foreigners played an important role in supervising trade activities in Javanese ports (Lombard, 1975; Suryo, 1985). The prosperity of Demak from trade is shown by the establishment of the Demak Mosque, as well as the City of Demak complete with the square, palace, market, as well as several ethnic settlements such as Kauman and Chinatown. For trading activities that serve internal needs, a market is prepared which is located east of the Alun-alun and adjacent to the Tuntang River. This is to facilitate the transportation of agricultural goods from rural areas. In the market, local handicrafts such as agricultural products, pottery, as well as export goods from China are also traded, such as silk, ceramic velvet, pottery, gold jewellery, jade, roots, umbrellas, from Persia such as perfume, medicines, rugs, from India such as cloth, jewellery, and so on. The market is designed to actively transact once per five days (following Javanese market days such as: Kliwon, Legi, Pahing, Pon, Wage). During the Demak Sultanate, there were already known religious ceremonies, namely Sekaten, Grebeg Maulud, and so on (Simuh, 1996). This cultural crowd is also a place for traders to carry out economic activities in public spaces, such as the square, mosque, and around the place of the ceremony. The bustle of the market shows the stretching of the people's economic activity, as well as the establishment of the socio-cultural life of the community. The market has an important role as a mechanism for controlling the ruler over his territory (Fauziah, 2019). The market also shows the hustle and bustle of a city, because the city is indicated by the type of livelihood of the population in the trade, service \& industrial sector which is more dominant than the agrarian sector. Demak in its heyday was one of the world's markets that controlled the Southeast Asia region area, and acculturation occurs through marriage, lifestyle, new social stratification, transfer of knowledge, entry of Islamic teachings, building technology, crafts, and so on. This makes the characteristics of the city of Demak in particular and the cities in the Northern Coastal of Java more open \& cosmopolitan. The success of the trading city gave rise to social stratification, namely the "trader class" or "trader businessman" who played an important role in the economy of the archipelago in the 16-18th century (Fauziah, 2019), which left the "noble class". The layout of the Islamic city of Demak, indicates that markets connected to ports and river transportation routes are important economic facilities on a domestic, regional and international scale. This is mentioned in history as a major factor in the development of cities in the North Coast of Java such as Gresik, Ampel, Tuban, Jepara, Kudus, Semarang, Cirebon.

\subsection{Character of Islamic Cities in the Northern Coastal of Java}

According to Suprapti (2015), generally the character of Islamic cities in the Northern Coastal of Java, found similarities in the existence of transcendental space, which are described below:

\section{Space to care for and preserve nature.}

\section{1.a. The sacredness of the tomb-mosque}

Javanese culture known by a tradition which are provided respects their ancestors which is commonly called "pepunden". The Javanese tradition of placing "pepunden" as a sacred ancestor and highly valued by the community can be seen from the placement of tombs embody a hierarchy (Pudianti et al, 2016). Most of the tombs of the Walisanga are located in mountains or hills, including the tombs of Sunan Giri, Sunan Bonang, Sunan Muria, Sunan Gunung Jati, etc. Spatially, it shows the existence of a vertical spatial hierarchy which is motivated by religious views. The tomb-masjid is designed to be a sacred space. This can be seen from the completeness of water sources for purification/ablution before entering the mosque or tomb building in Ampel, Gresik, Kudus, and Demak. In Kudus, Gresik in order to reach the tomb, one has to bow through a low gate as a symbol of respect to the Walis. The tomb of Sunan Kudus is closed with a mosquito net, to care for this mosquito an 'buka luwur' ritual is carried out which is attended by ulama, community leaders, and the wider community. 
The phenomenon of integration between nature, space, time and the existence of this community is in accordance with the view of Eliade (1959).

Meanwhile at the Sunan Ampel tombs sites Surabaya and the Sunan Kalijaga tombs sites Kadilangu Demak, because they are far from the mountain, the tombs \& mosques are located in the lowlands and close to the river and have developed into residential centers (see Figure 2).

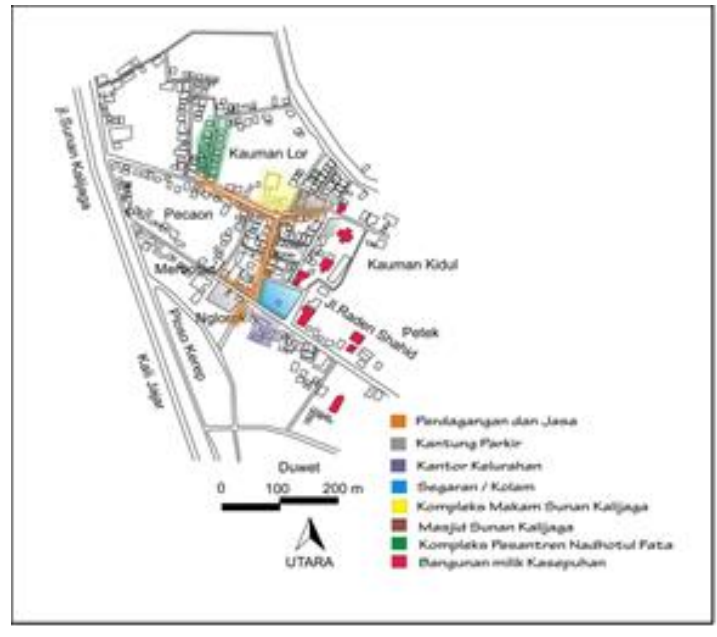

Figure 2

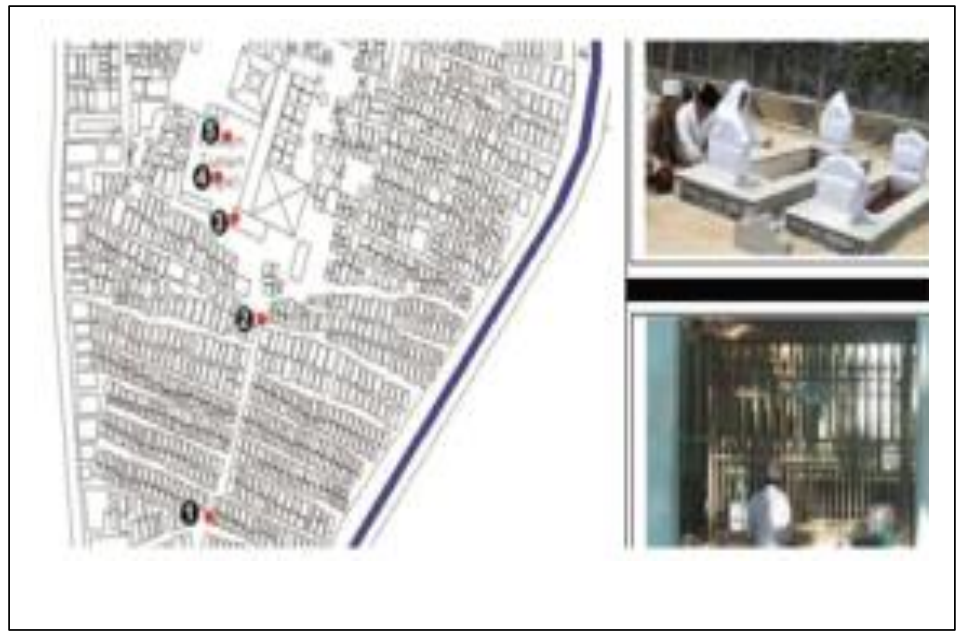

Map of Ampel \& Kadilangu Areas; Above: Tomb of Sunan Kalijaga in the center of the settlement of Kadilangu Village; Below: Tomb of Sunan Ampel in the center of settlement (Source: Suprapti, 2016)

\section{1. b. Blessing space}

Blessing space (Barakah) is used in daily life for social, economic, religious activities, People believe it can provide happiness, prosperity, feel secure and save for them (Suprapti et al., 2015; Pudianti et al., 2016). Residents who live around the sites of Sunan Ampel, Sunan Kudus, Sunan Muria, and Sunan Kalijaga believe that the land they occupy is full of blessings in the world and the hereafter, it makes them feel happy to stay there.

\section{Creative economy space}

Creative economy space is a space located around a tomb/mosque which is a facility for the development of creative economic activities, so that it can improve the economy of the surrounding community. This space grows and develops in all sites and becomes the economic support for the population along with the development of religious tourism. The space is in the form of a market that has been well laid out by the government as a place to trade typical souvenirs. In Kudus Kulon creative people develop embroidery crafts, Muslim batik clothing, while at the Sunan Muria site, residents sell typical crops from the Mount Muria such as fruit and vegetables. In Kadilangu area grew drum and batik craftsmen. While in other places, most of the commodities sold are typical Muslim souvenirs imported from various places. This creative economy space can still be developed to increase added value economically, which is supported by the creativity of the population by means of community empowerment.

\section{Tolerant space}

This settlement has a high cultural tolerance. In Ampel, around the tomb is a place of residence with a high heterogeneity, including ethnic Madurese, Javanese, and Arabs. Meanwhile in 
Kudus Kulon the heterogeneity consists of Javanese, Arab, and Chinese ethnicities. Here the influence of Chinese culture has strengthened since Sunan Kudus spread Islamic teachings together with Kyai The Ling Sing, cultural acculturation appears to appear, among others, in the gebyog (wooden) carving motif, the Menara building which is located next to the Al-Aqsa Mosque, the structure and layout of the Joglo Pencu building. Meanwhile, ethnic Arabs spread in the Ampel site, Kudus site, Gresik site, cultural acculturation to appear in culinary, residential architecture, lifestyle, trade, etc. The potential for tolerance is the key to unity among diversity that needs to be maintained for the sake of the integrity of the nation.

\section{Syiar (Teaching Islam) space.}

\section{4. a. Symbols of the history of Islamic development}

The buildings of tombs, mosques, towers, gates, typical residences found at the Walisanga site and its surroundings are historical architectural works and are symbols of Islam. Likewise, these artifacts are part of a living heritage who live sustainably and have deep meaning for their communities. In Kudus the residential building 'joglo pencu' is a 'masterpiece' of wooden house architecture in the North Coast of Java. The community strives to care for, maintain and preserve so that it can be sustainable and still exist today and in the future.

\section{4. b. Religious education institute}

Many Islamic boarding schools spread around the various sites of the Walisanga's mosques. It aims to foster the morality of future generations. The Ampel Denta area is known as the birthplace of the Islamic boarding school from Sunan Ampel which is the place of Walisanga's education, currently there are two Islamic boarding schools here. In Kudus Kulon area there are 23 (twenty-three) Islamic educational institutions consisting of Islamic boarding schools and madrasah.
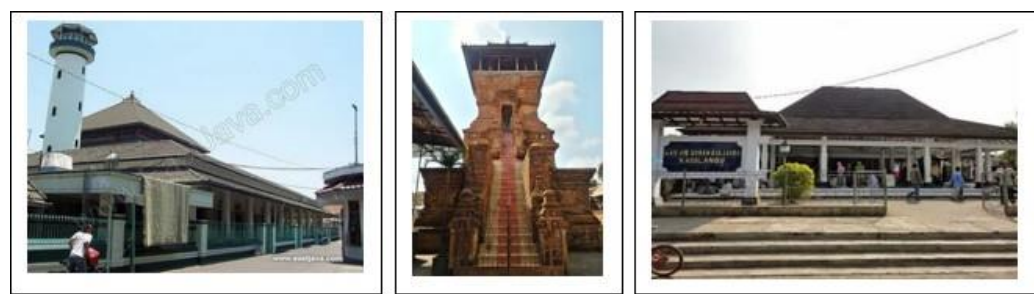

Figure 3

Left: Sunan Ampel Mosque; Middle: Menara Kudus, a legacy of Sunan Kudus;

Right: The Kadilangu Mosque, the legacy of Sunan Kalijaga Kadilangu (Source: field survey, 2019)

\section{Political space}

The tombs of the Walisanga have political power. Historically, politicians from the first president of Soekarno to the current President of the Republic of Indonesia (Joko Widodo) have often visited the Walisanga religious site, except for the Sunan Kudus site, which according to the myth is taboo to be visited by unclean character of politicians. This area is often used by interested parties to gain political support.

The concepts of space as a result of the empirical findings of the research above, are the essence of a worldview based on the sources of Islamic teachings and Javanese culture which are applied in the daily life of the Javanese-Islamic city settlement community.

\subsection{The Historical area of Kudus Kulon}

Kudus is the unique of Islamic heritage city which has a high population density in Kota District (BPS, 2021) reaching 8,546 people per km square and continues to increase while 
the average in Central Java is 1,113 people per $\mathrm{km} 2$, as well as the growth rate population $0.34 \%$ while the average in Central Java is $1.17 \%$. The dynamics of the urban population have an impact on cultural acculturation, making it vulnerable to cultural changes, especially in architectural styles. The Kudus Kulon area is located on the west side of the Gelis River, ethnically-sociologically it is a traditional settlement that is distinguished by history when compared to the more recently formed Kudus Wetan settlement. The observation area of Kudus Kulon includes Kauman, Work and Langgar Dalem, Demangan, Damaran, Kajeksan.

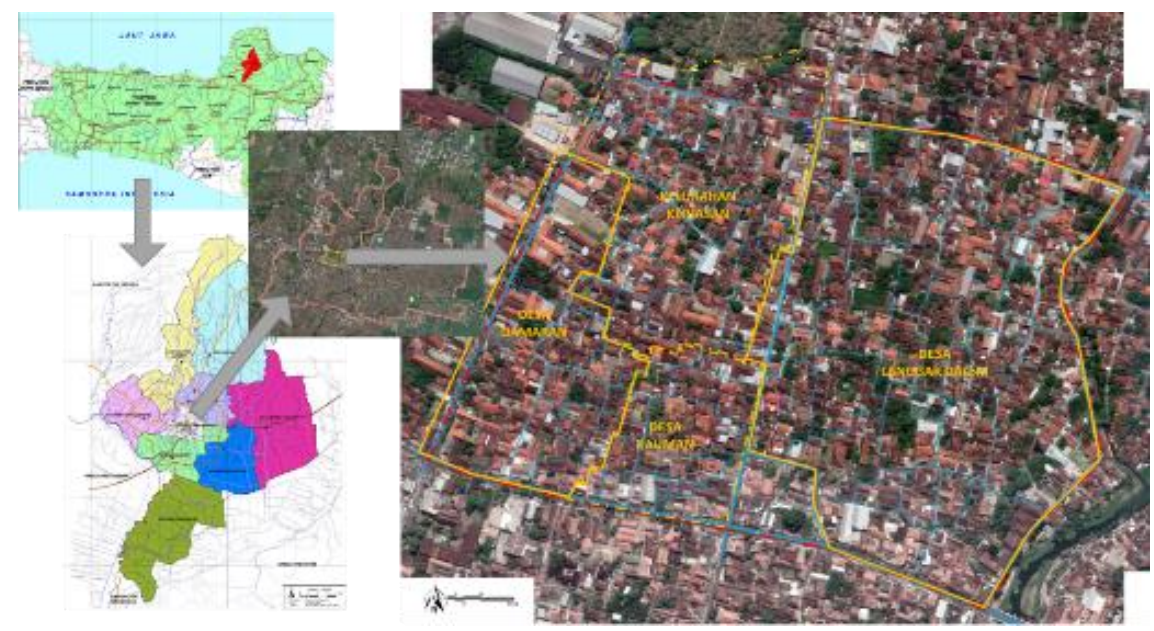

Figure 4

Location of the historical settlement of Kudus Kulon, Kudus Regency

(Source: Suprapti, 2020)

The Kudus Kulon area is an area was developed by Sunan Kudus in the 16th centuries period. The traditional house building is typical of Kudus joglo pencu with the Gusjigang community being the most widely spread in this location. The joglo pencu house has a knock down wooden frame structure system, using only wooden pegs influenced by the Chinese Yin-Yang concept, this structure is also proven to be earthquake resistant. However, due to the ease of disassembly and installation, this building can be moved easily. So that it become the target of investors because it is considered an antique. The composition of doors, consoles, blandar (beam), bancik (foot step), and ornamentation in the jogosatru space creates the grandeur and luxury of the Kudus house. If the joglo building is for the aristocratic class, the joglo pencu is more egalitarian, which is dominated by traders can be seen in figure 5.
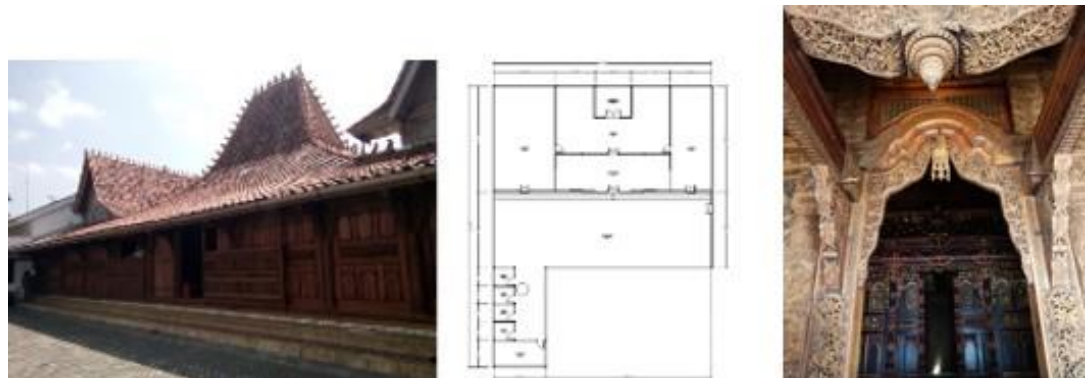

Figure 5

Left and midle: Joglo pencu house in Kauman village has complete layout and well maintained; Right: Detailed carvings of the highest quality in the Jogosatru room 
Kudus Kulon residents call themselves as the Gusjigang community, namely people who have good morals, are good at the Qoran and trade. This is related to the teachings of Sunan Kudus, a prominent member of the Walisanga who spread Islam along with the cleric from China, namely Kyai The ling Sing in the 16th century, after the fall of Majapahit. Kyai The Ling Sing who came with Cheng Ho taught his skills in wooden carving, so that the gebyog craft with very high artistic value developed. Meanwhile, Sunan Kudus emphasizes the application of a balance between the life of the world and the hereafter. The representation of devout Muslims who limit themselves from the evils of the world, the existence of communal space as a reflection of community cohesion, and high privacy as a way of protecting from crime (Suprapti et al., 2014). This condition is relatively still preserved as the original. According to Sardjono (2016), the layout of the joglo pencu house includes the dalem (main house with a joglo pencu roof, consisting of jogosatru which means living room, gedhongan means bedroom, and jogan which is in front of gedongan, pawon is on the left or right or the back of the house). Sisiran (work place), and regol (gateway), and the presence of soko gender (wooden column) symbolizing the oneness of God, in the jogosatru room, which shows that there is a difference with Joglo. A distinctive uniqueness is found in gebyog (carving wooden wall) with detailed carvings and has a philosophy of life that is different. In addition to the forms of cloves, jasmine flowers, pineapples, phoenixes, dragons, crowns which show the acculturation of Javanese, Hindu, Islamic, Chinese, Persian and European cultures (Ekarini, 2016). The joglo pencu house is a representation of the perspective, ideas, way of life, and lifestyle of the Gusjigang Kudus Kulon community.

Kudus grew into a city of character and prosperity. Acculturation appears in the inherited artifacts and local culture that is still well-maintained today. The building of the Al-Aqsa Mosque and the Menara tower with the tomb complex of Sunan Kudus around it architecturally gets influences from Hindu culture, has become a landmark of the Kudus City (Wikantari, 1994). The joglo house is widely known in Java, but the typical Kudus joglo is known by the local community as 'pencu', which indicates a different character of the original joglo form which is based on socio-cultural background and adaptation to the natural environment. The daily life of the Kudus people is colored by socio-cultural life, trading and the Qoran, therefore they are known as the Gusjigang community (Sardjono, 2016). The age of the omah joglo pencu is between 150 years (Wikantari, 1994) to 270 years (Ashadi, 2010). However, the passage of time marked by changes in the political and economic landscape gradually shifted the success of the Kudus Kulon traders to a condition that was no longer successful. The city of Kudus is closely related to its identity as a successful Muslim city on the Northern Coastal of Java, and the passage of time proves that the history of life continues to this day. Socio-cultural values passed down from generation to generation in the course of time are the key to the living heritage of Kudus Kulon. The resilience of omah pencu with indigenous, tribal values is a work of vernacular architecture (Oliver in Martana, 2006), which refers to community culture, the natural environment, sourced from customs and traditions (Prijotomo, 2004; Pangarsa, 2007). These values should be preserved (Bernard, Schellen, 2019). The tangible values of the joglo pencu house and the intangible values of the Gusjigang community in the historic area of Kudus Kulon mark the spread of Islam and acculturation in Indonesia and evidence of the sustainability of an important historical civilization that cannot be found anywhere else. From the research of Suprapti et al. (2020) who carried out digital mapping of four villages in Kudus Kulon found that there are still 50 units of omah joglo pencu with various conditions. Regarding the current, the conditions of omah joglo pencu can be seen in Figure 6 below. 


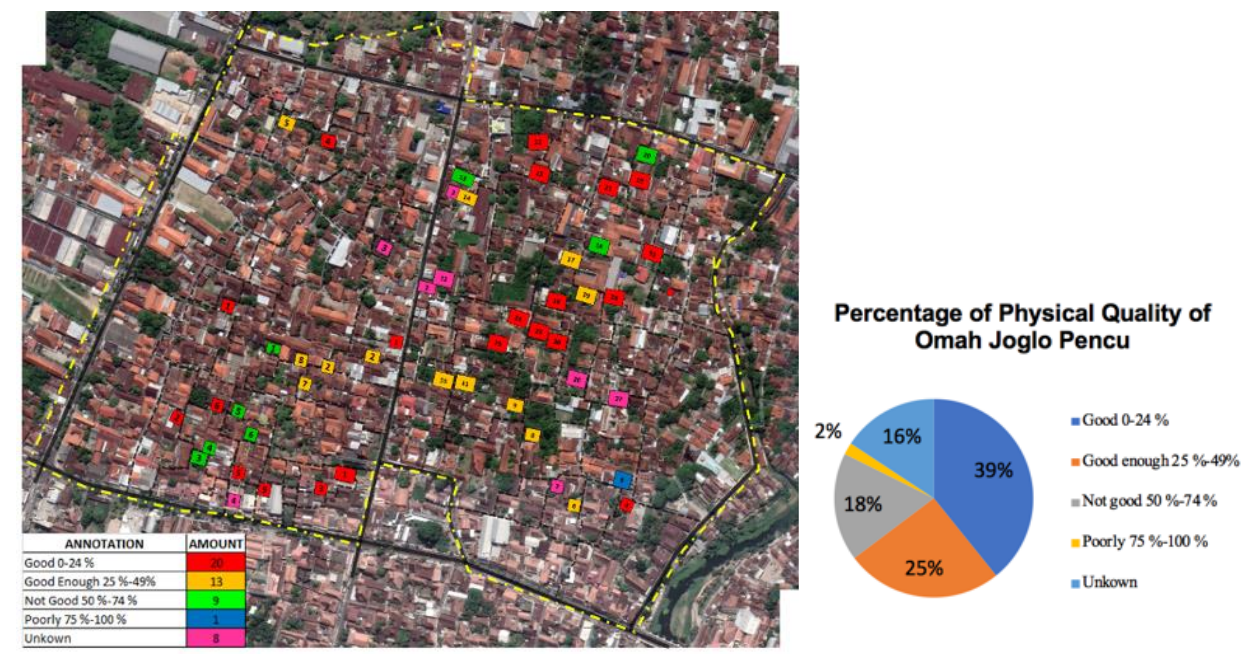

Figure 6

Digital Mapping for omah joglo pencu based on building physical quality

(Source: Suprapti et al 2020)

\section{Percentage of Omah Joglo Pencu Based on the Building Openness}

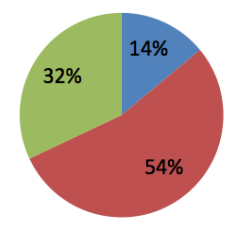

- Gebyog in a row

- Single Gebyog

Kilungan Gebyog

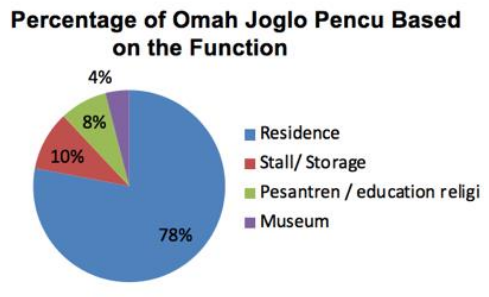
Percentage of Omah Joglo Pencu Based on
the Roof Shape

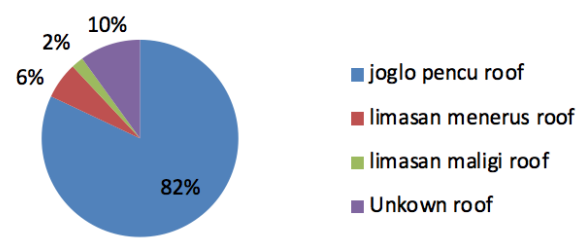

Figure 7

Left top: The percentage of omah joglo pencu based on the building openness

Right top: percentage of omah joglo pencu based on the function

Right bottom: Percentage of omah joglo pencu based on roof shape

Right bottom: Percentage of omah joglo pencu based on spatial layout

(Source: Suprapti et al 2020)

The sustainability for Kudus Kulon city through the living heritage approach, could be obtained through three aspects, namely 1) historical and cultural sustainability, 2) functional sustainability, and 3) care for continuity with digital technology. 


\section{Historical \& cultural sustainability}

The historical area of Kudus Kulon is an inheritance place from Walisanga believed having a blessing which is able to provide security, safety, prosperity for residence. It is a historical place from Sunan Kudus, who has promoted the concept of tolerant culture of the Gusjigang community time by time. Omah joglo pencu is a variant of the joglo (Javanese) building in the Northern Coastal of Java which is full of cultural values. Philosophically, it is a symbol of the spread of Islamic teachings, and a symbol of acculturation (Suprapti et al., 2014; Suprapti et al., 2020) between Hinduism, Buddhism, Islam, China, Java, Persia and Europe. From the aesthetic aspect as well as earthquake-resistant construction and spatial planning adapting from Islamic culture after previously taking the form of the Javanese joglo house (Sardjono et al., 2016 in Suprapti et al., 2020).

\section{Functional sustainability}

The function of this historical area of Kudus Kulon is as a residence for the Gusjigang community, as a place for political business, to spread Islamic teaching, to serve education. The omah joglo pencu is a testament to the passage of time that facilitates the activities of the Gusjigang community. Architectural layout works well to accommodate the daily attitude of the community which is based on socio-cultural and religious values. The Madrid conference resolution 1904 (Wijesuriya, 2012) conveys the division of heritage monuments into dead monuments that are the result and purpose of the past and living monuments that continue to serve their original purpose or function. According to Wijesuriya (2012) the conservation of living heritage in historic areas must be restored to its condition related to its aesthetics and function as a means.

\section{Care for continuity with digital technology}

The Gusjigang community as cultural heirs have lived together throughout history with the artifact of the omah joglo pencu. This community is responsible for the existence of the buildings tomb-mosque, joglo pencu houses and others; keep its sacredness; take for nature and environment surrounding. However, this is not easy, especially in facing the economic conditions that have been shifted from their heyday. So many buildings are not well maintained, and even sold because of difficulties in financing for maintenance.

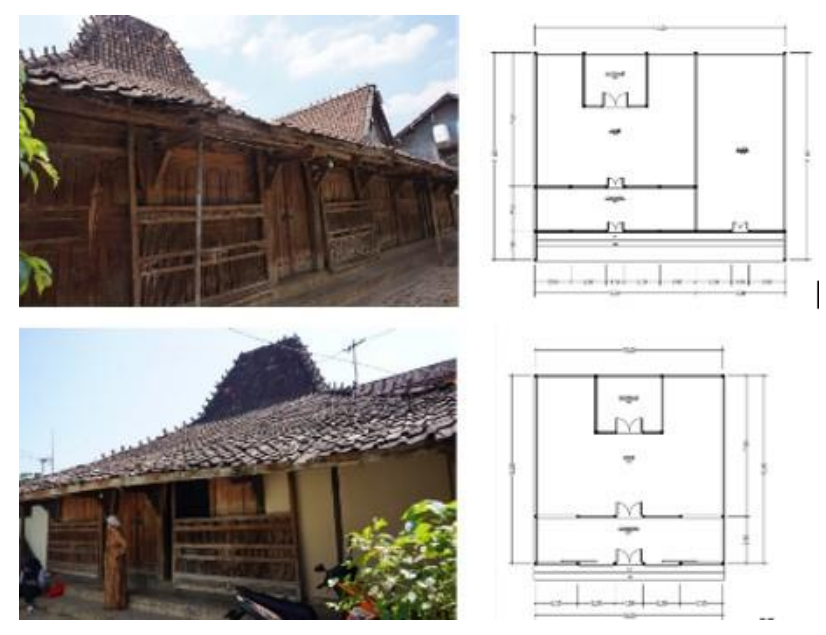

Figure 8

Above: The poorly maintained condition of the omah joglo pencu and the plan of omah joglo pencu consisting of dalem (main house) and pawon kitchen Below: omah joglo pencu's floor plan consists of dalem only

(Source: Field Survey 2019) 
In the 21 st century, the development of digital technology has spread rapidly to all corners of society in the field of social communication, leaving analogy technology. The emergence of social media as a communication tool that unites space and time is suspected to be the cause of the emergence of a digital society. The availability of software applications, smart phone communication devices, and the availability of broadband access are the catalysts for consumers to be ready connected at any time (Kuswarno, 2015). The development of ICT and digital data has influenced the research and production process of science in the social sciences and humanities (Roth, et.al. 2019) both methodologically, data provision and analysis process. There is no doubt about the ability of digital technology to provide possible datasets (Kitchin, 2014; Crombez, Dahmn, 201 Some previous studies on the concept of preserving culture still use conventional methods. In the fast-paced rhythm of urbanization, innovation patterns should be applied in maintaining cultural values). one of the local values is the cultural mapping technique. It is able to provide new insights in an effort to combine digital mapping patterns with a webGIS-based information system to map cultural sites (Municipal cultural Planning Incorporated, 2010) such as omah joglo pencu. This becomes important when technology must be able to answer challenges particularly in maintaining and protecting traces of the richness of past traditions which have their own meaning for the civilization of a nation. As stated by Freitas (2016) that one form of maintaining cultural values is to create good data and track records so that historical values are mapped well. In line with this thought, Zoderer et al (2016) tried to make an innovation by mapping cultural-based tourist areas. Furthermore Oikonomopoulou et al. (2017) assessing a history in the form of archaeological archives. These forms of research efforts have not utilized a digital mapping model based on webGIS. Several studies conducted by previous researchers on the uniqueness of the historical area of Kudus Kulon have produced data about the omah joglo pencu from floor plans, looks, pieces that explore physical characteristics (Wikantari 2001, Suprapti 2016); the character of the Gusjigang community and the character of the residential environment (Sardjono, 2016), however, a web-GIS-based digital mapping of the joglo pencu house is needed which can be a database, informing the location of the building, historical background, current architectural conditions. This is needed to maintain cultural values by mapping the location of the omah joglo pencu as well as providing information about the architectural character and condition of the building and designing it in a web-based geospatial system. As an initiative to assist the community in protecting cultural assets, especially in this area. The developed WEbGIS technology is able to answer problems and questions related to location information. This is able to help local governments, especially in urban conservation efforts and in making development decisions related to historical sites in urban areas. The purpose of using WebGIS is to show an initiative that bridges the digital world with the cultural community that still preserves the omah joglo pencu as one of the unique buildings and has historical value in Indonesia. Furthermore, the challenges of digital mapping and its application as a decisionmaking system for urban conservation policies, so as to provide benefits to communities in urban areas and are able to provide accurate information as an urban conservation innovation.

\section{A living heritage approach in Kudus Kulon area}

The role of stakeholders is very important in the practice of sustainable living heritage. Looking through the Kudus Kulon case the living heritage approach can be done through collaboration of stakeholders, which can be described below: 


\section{4. a. Building owners}

Not all building owners are identical to the residents of the omah joglo pencu. If not inhabited by the owner, usually this house is not functioned as a residence but as a place of business such as contract houses, warehouses, Islamic boarding schools, museums. Meanwhile, of the 50 housing units found at the research site, it is known that the residents who are direct descendants of the building's founders amounted to $56 \%$. According to several sources, the founder of the omah joglo pencu has a background of traders/entrepreneurs, this can be understood if it is related to the estimated value of the construction of omah joglo pencu complete version with spatial planning, architectural forms, and carvings of gebyog which can reach 7.5 billion rupiah (Purwanto, 2017). Caring for a wooden building with intricate carvings aged hundreds of years is not an easy thing, in addition to requiring certain techniques, it also costs a lot of money. Along with the passage of time, their business experienced a period of receding, precisely in the period from the early 20th century to the 1970s. Meanwhile the percentage of buildings that are still in good condition is $39 \%$, this illustrates the difficulty in building maintenance, especially related to funding. Due to the high maintenance costs, not all building owners can carry out routine maintenance.

The intended treatment fund support from the government, but not for all. Research in this area shows that $78 \%$ of the function of the building is still used as a residence (see Figure 8 ). The dominance of the function as a residence contributes to the resilience of the building, but also at the same time its vulnerability. Several informants who still care for and look after omah joglo pencu explained that they actually love and like it, but often encounter expensive maintenance costs.

The tradition of the omah joglo pencu as an 'inheritance house' allows this house to be distributed to a number of descendants. Based on this tradition, the joglo pencu can be divided into parts such as dalem, pawon, sisiran, so that the heirs will get these parts. The division allows the complete loss of parts of the omah joglo pencu, and even finally it can be lost without a trace due to the persuasion of billions of rupiah from collectors of antique objects (Prayitno, 2019). Due to the demands of the economy and social media, one can easily offer the joglo pencu to potential buyers who generally come from entrepreneurs, investors from within and outside the country.

As building owners, they are also direct descendants of the building's founders, who are currently in the fourth to seventh generation. Over time, the tangible and intangible aspects have been integrated and have a reciprocal relationship between the two, this is known as living heritage (Poulios, 2014). Living heritage is a challenge for sustainable development of cultural heritage areas, which is entirely a community-based approach (De Caro and Wijesuriya 2012; Poulios 2014). Besides, this situation allows the preservation of the sense of place (spatial character) which will maintain sustainability between tangible and intangible aspects (Tan, Tan, Kok, \& Choon, 2018). The intensity of social relations between these communities is relatively high, because the majority of residents have good kinship relations, and they are bound in one social religious group that carries out routine activities in socialreligious meetings once per week in one of the residents' houses in turns. The preservation efforts of the residents are constrained by economic problems and heirs.

\section{4.b. The Foundation}

This foundation seems to care about tangible and intangible assets left by Sunan Kudus, including the omah joglo pencu. This foundation was founded in the 1980s by the administrators of the Sunan Kudus Mosques, currently led by $\mathrm{KH}$ Em Nadjib Hassan. The foundation has the responsibility to maintain the care, the Tomb Area, \& the Tower Mosque which was founded by Sunan Kudus in $956 \mathrm{H}$ or $1549 \mathrm{AD}$, as well as the existing cultural and religious traditions to the pilgrims, as well as the surrounding community. The Foundation of 
YM3SK's social activities include maintain local culture tradition like Buka Luwur, and Dandhangan:

Currently the Foundation has two representative units of omah joglo pencu. One unit is located on JI. Sunan Kudus received from a grant from the foundation administrator. This building was moved back and underwent maintenance by replacing some damaged wood materials. The newest building owned in 2017, is from the category of very excellent omah joglo pencu which is complete with architectural layout and very good quality gebyog and original. Both buildings will be utilized as museums.

The role of the Foundation in maintaining and preserving the omah joglo pencu is a very good potential. This is because of the place attachment factor caused by place identity, place dependence, and place bonding factors (Goussous, Al Hammadi, 2018). However, there are still weaknesses where the efforts made have not been integrated with the community and other stakeholders.

\section{4.c. Academics}

Academics program can be carried out through the activities of the tridharma of higher education. The living heritage area with all its potentials and problems is an asset of the "living laboratory", which is a place for research to be carried out both for the development of science, as well as for teaching development, especially in facing the Independent curriculum which can involve multidisciplinary sciences such as architecture, civil engineering, computer engineering, etc. with the 'problem based learning' method. Community service activities such as thematic community service program, can be considered to provide solutions to the problem of living heritage conservation from several disciplines.

\section{4.d. Private Sector}

The private sector plays an important role in the era of digital platforms, especially in disseminating issues that are both public and private (Dijck, 2019). And furthermore, the participation of private and public actors is needed actively through the entire preservation process (Balarezo et al., 2017; Absalyamov, 2015)

\section{4.e. Wood Crafts (Carpenters)}

These craftsmen inherit and develop traditionally knowledge to future generations, through practice. These craftsmen hold the omah pencu standard and the motifs of the Kudus gebyog carving. It seems that it is in the hands of these craftsmen that the heavy task of maintaining the tradition of omah joglo pencu Kudus is entrusted, because their responsibilities are not only economic matters, but also the sustainability of traditions and culture.

\section{4.f. Government}

Efforts made by the government through the Department of Tourism, among others, are the designation of this omah joglo pencu as a cultural heritage object in 2009. For this reason, a reduction in PBB by $50 \%$ is given. Maintenance assistance funds have also been launched to owners of omah joglo pencu, although the amount is insufficient. However, the sale of omah joglo pencu are frequently occur.

\section{4.g. The Role of Social Media}

In the digital era, the use of social media has become a necessity and people's daily lifestyle. By utilizing a web-browser, information about omah joglo pencu can be obtained easily from websites such as Facebook, online press, Tokopedia, YouTube, Twitter, Instagram, and blogs. 


\section{Conclusion}

Islamic city as Ampel, Gresik, Demak, Kudus, Cirebon has a potency fo living heritage in which it grows together between artifacts in the form of mosques, tombs, markets, educational institutions, open spaces, settlements and communities. which supports it is the result of the tangible and intangible culture of Javanese coastal Islam continuously throughout its lifetime. These local identities have high value and are meaningful for the community, but are currently facing threats both internally due to age, economic problems, and traditional management.

For this reason, collaboration between stakeholders, both the community, the private sector, government, academics, technicians are needed so that they can synergize. Utilization of digital technology is needed for archiving so that interesting local knowledge becomes information that is easily accessible to all parties globally, to facilitate monitoring and management by the community and all stakeholders. Cooperation is needed between all stakeholders, including building owners, government, community, private sector, craftsmen, academics, etc., to synergize in an integrated and structured management, so that village management runs effectively, efficiently and optimally.

Sustainability of an Islamic city through a living heritage approach can be done by encouraging historical - cultural values, functional aspects, and continuity of care by utilizing technology. The use of digital technology will facilitate the continuity of maintenance and preservation through the preparation of a database, mapping, delivery of location information, building conditions, architectural characteristics into the network system, monitoring, opportunities for stakeholders to synergize, encouraging systematic preservation.

Suggestions for the research development is to conduct the researches related to preservation management.

\section{Acknowledgments}

Author conveys acknowledgment to Dean of Engineering Faculty and Head of Architecture Department UNDIP Prof. M Agung Wibowo, PhD. and Dr, Agung Budi Sardjono, MT UNDIP, and also team of Undip's Senators, those who have contributed supports and motivations so that the article have been done. The part of the article contents, was once delivered by author in the Professor's inauguration speech.

\section{References}

Abu-Lughod, J. L. (1987). The Islamic city--Historic myth, Islamic essence, and contemporary relevance. International Journal of Middle East Studies, 19(2), 155- 176.

Ainiyah, N. (2013). Pembentukan karakter melalui pendidikan agama Islam. Al- Ulum, 13(1), 25-38.

Al-Qahtany, H. M. (2009). Islamic architecture as a reflection of functionalism and interactionism: conceptual origins in culture and sociology. Contemporary Arab Affairs. https://doi.org/10.1080/17550910902875762

Al-Qurtubi, A. A. M. bin, \& Al-Ansari, A. (1964). al-Jami'li Ahkam al-Quran. Kairo: Dâr Al-Kutub Al-Mi Riyyah.

Balarezo, A., C., M., Vázquez, L., J., ., Barsallo, G., M., Briones, C., J., Amaya,

J. 2017. Strategies for the management of built heritage linked to maintenance and monitoring, case study of the San Roque neighbourhood, Cuenca, Ecuador. The International Arvhives of the Photogrammetry, Remote Sensing and Spatial Information 
Sciences, Vol XLII-2/W5.

Absalyamov, T. 2015. Tatarstan Model of Public-Private Partnership in the Field of Cultural Heritage Preservation, Procedia - Social and Behavioral Sciences, Vol. 188, 14 May 2015, p 214-217

Darban, A. A. (1984). Kampung Kauman: Sebuah Tipologi Kampung Santri di Perkotaan Jawa (Studi Perbandingan Sejarah Pertumbuhan Kampung Kauman Kudus dan Yogyakarta).

Dijck, V., J. (2019): Governing digital societies: private platforms, public values, Computer Law \& Security Review, Article in Press

Eliade, M. (1959). The Sacred and the Profane: The Nature of Religion, New York, Harcourt Brace Jovanovich.

Fauziah, N. (2019). Analisis Kecurangan Dalam Timbangan Sembako Menurut Perspektif Hukum Islam Di Pasar Pendidikan Krakatau Medan. Skr Ipsi.

Hakim, B. S. (1986). Arabic-Islamic Cities. Building and Planning Principles.

Hayden, D. (1994). The power of place: Claiming Urban Landscapes as People's History. Journal of Urban History. https://doi.org/10.1177/009614429402000402

Hielmy, I. (2000). Wancana Islam. Ciamis: Pusat Informasi Pesantren.

Hillier, B., \& Hanson, J. (1988). The social logic of space. The Social Logic of Space. https://doi.org/10.4324/9780429450174-9.

Kuswarno, E., 2015 Potret Wajah Masyarakat Digital, Jurnal Communicate Vol 1, No 1 4753

Lang, W., Chen, T., \& Li, X. (2016). A new style of urbanization in China: Transformation of urban rural communities. Habitat International. https://doi.org/10.1016/j.habitatint.2015.10.009

Legeby, A. (2013). Patterns of co-presence: Spatial configuration and social segregation. In Usab.

Lombard, M. (1975). The golden age of Islam. North-Holland Publ. Lynch, K. (1960). The image of the city (Vol. 11). MIT press.

Muhakamurrohman, A., \& others. (2014). Pesantren: Santri, kiai, dan tradisi. IBDA: Jurnal Kajian Islam Dan Budaya, 12(2), 109-118.

Norberg-S, C. (1983). Heidegger's thinking on architecture. Perspecta, 20, 61-68.

Oikonomopoulou, E., Delegou. E. T., Sayas J., Mouropulou, A (2017). An Innovative Approach to the protection of cultural heritage: The case of cultural route in Chios Island, Greece. Journal of Archaelogical Science: Reports, 14, 742-757. https://doi.org/10.1016/j.jasrep.2016.09.006

Pudianti, A., Syahbana, J. A., \& Suprapti, A. (2016). Role of culture in rural transformation in Manding Village, Bantul Yogyakarta, Indonesia. Procedia- Social and Behavioral Sciences, 227, 458-464.

Poulios, I (2014) Discussing strategy in heritage conservation- living heritage approach as an example of strategy innovation. Journal of cultural Heritage Management and Sustainable Development, 4 (1), 16-

Rahman, S. A., \& Wahab, M. A. (2004). Psikologi Suatu Pengantar dalam Perspektif Islam. Jakarta: Prenada Media.

Rapoport, A. (1970). The Study of Spatial Quality. Journal of Aesthetic Education. https://doi.org/10.2307/3331287

Rapoport, A. (2002). The role of neighborhoods in the success of cities. Ekistics.

Raymond, A. (1994). Islamic city, arab city: Orientalist myths and recent views. British Journal of Middle Eastern Studies. https://doi.org/10.1080/13530199408705589

Roth, S.,Dahms, F.,H., Welz, F., Cattacin, S. (2019) Print theories of computer societies. Introduction to the digital transformation of social theory. 
Saoud, R. (2002). Introduction to the Islamic City. Foundation for Science Technology and Civilisation.

Sari, F. K., Farida, F., \& Syazali, M. (2016). Pengembangan Media Pembelajaran (Modul) berbantuan Geogebra Pokok Bahasan Turunan. Al-Jabar: Jurnal Pendidikan Matematika, 7(2), 135-152.

Suprapti, A., Budi Sardjono, A., Rochma, H. A., \& Yasmina, N. F. (2014). The Tradition of Living of Muslim Community Kuduskulon. Journal of Social Sciences, 10(2), 63-73.

Suprapti A, Indriastjario, Sarjono A.B., 2015. The Urban Heritage of Masjid Sunan Ampel Surabaya, Toward the Intelligent Urbanism Development. CITIES 2015 International Conference, Intelligent Planning Towards Smart Cities Procedia - Social and Behavioral Sciences Volume 227: 601-608

Supapti, A., Kim, S., Pandelaki, E.E, \& Firmandhani, S. W (2018). a Spatial Dialogue of Heritage Village Between Kauman in Semarang and Seochon in Seoul Toward Preservation Development. Journal of Architecture and Urbanism, 42(1), 16-23. https://doi.org/10.3846/jau.2018.1478

Suprapti, A., Kistanto, N. H., Pandelaki, E. E., \& Indrosaptono, D. (2017). Control of spatial protection in Kauman Semarang. Journal of Architecture and Urbanism, 41(4), 268-277.

Suprapti, A., Sejati, W, A, Sarjono A.B., Pandelaki, E. E. (2021). Toward Sustainable Preservation of Cultural Heritage Buildings; A Combination of Digital Mapping and Architectural Mapping for Omah Pencu in the Historic Area of Kudus Kulon, Jurnal Teknik, 41 (3), 2020, 201-211.

Wijesuria, G. (2017). Toward the de-secularization pf heritage. Built Heritage 2. Pp 1-15. (Article). Icomos Open Archive.

Wikantari, R. (2001). Prospect of Public Alley and Shared-Passade in The Historic Area of Kudus Indonesia, Based on the Residents Evaluation. Jos of Jurnal of Architecture and Planning (Transaction AIJ) 66(545):197-205 